\title{
Corneal transplant wait list varies across Canada
}

$\mathrm{T}$ he 2000 to 3000 Canadians on wait lists for corneal transplants today may linger there for up to three years, depending on where they live. Meanwhile, south of the border, Americans have no wait time for the procedure.

The problem in Canada is the lack of corneal tissue.

"If you don't have corneas, you can't do any surgery," says Dr. Paul Dubord, a Vancouver surgeon, corneal transplant specialist and World Health Organization corneal expert. "The problem is leadership. Eye banks are not governed on a national basis instead, each province takes care of its own, and that's where the problem is."

Residents of British Columbia wait four to six months; those in Alberta and Ontario can wait two to three years.

Quebec is the only province that has solved the problem. Residents there used to wait years, but in 2008, Héma-Québec began coordinating the province's three eye banks. Its goal was to meet demand by increasing donations from roughly 200 per year to about 800 .

Héma-Québec began by purchasing corneal tissue from eye banks in the United States - a third of its supply is still imported - but it also increased donations by trying to motivate frontline hospital staff who have access to the families of recently deceased persons, says Dr. Marc Germain, vicepresident of medical affairs at HémaQuébec. "The vast majority of people are quite willing to donate their organs and tissues when they die, but someone has to remind them of that possibility."

Since Héma-Québec took over corneal supply, the wait for a cornea transplant in Quebec ranges from a couple of weeks to a couple of months, depending on the availability of the 14 surgeons who perform these surgeries.

Canadian Blood Services has tried to solve the wait-time problem elsewhere in Canada. In April 2011, it published Call to action: a strategic plan to

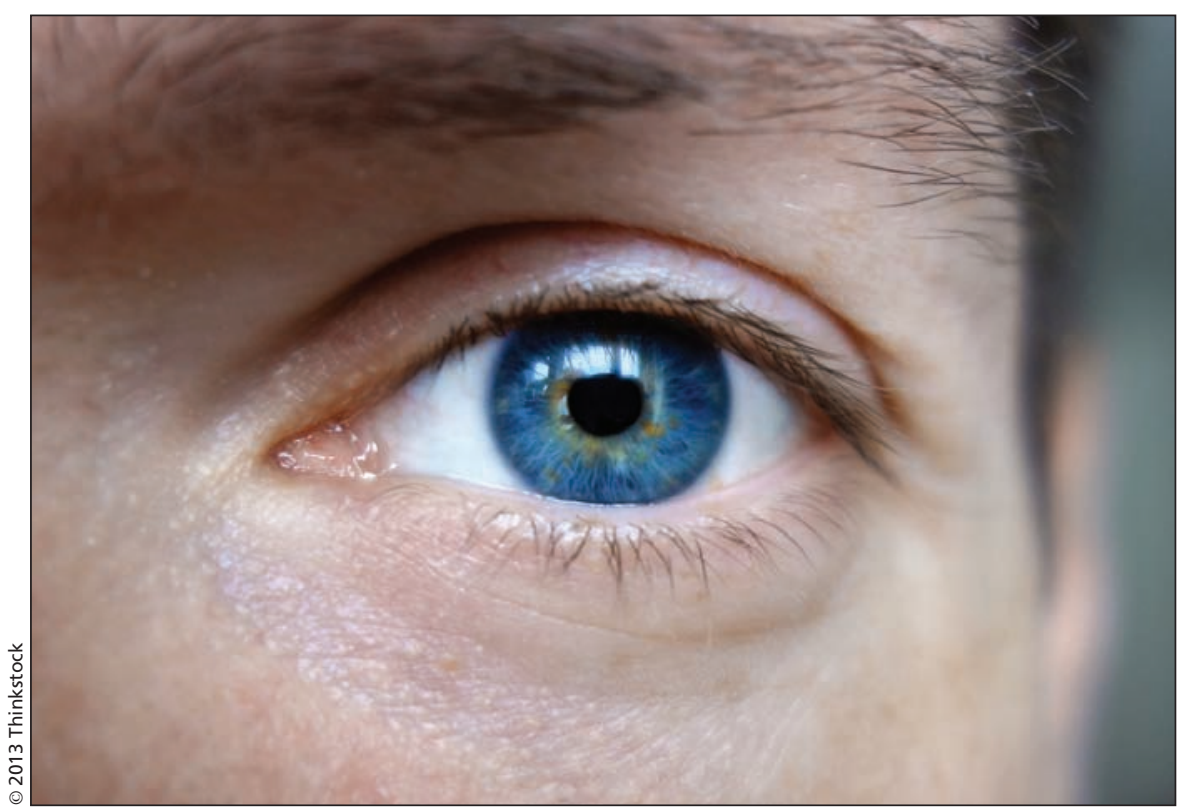

Canadians have to wait for corneal transplants primarily because of the lack of availability of corneal tissue.

improve organ and tissue donation and transplantation performance for Canadians, which made recommendations on resolving some of the most pressing issues. To begin with, it advised importing corneas into Canada while domestic supply was being accelerated.

Its biggest call to action was for a fundamental reorganization of the way cornea donation, recovery, processing and distribution is done, structured on an interprovincial basis, with one system that serves all the provinces simultaneously, said Mathias Haun, director, strategic planning, tissues, at Canadian Blood Services.

Two years have passed since the action plan was released, but Haun remains optimistic. "We know the ministries of health are looking at this, and we have every reason to believe it will move forward," he says. "But it's hard to predict when the change might start."

The reason there's an insufficient supply of corneas in Canada is that we're not realizing all the potential opportunities for cornea donations, says Haun.

"Most of the public gets how important organ donations are because it's often life or death for people who need those organs. Cornea transplantation doesn't resonate as much; it's not perceived as having that same level of gravity," he reflects. "But people waiting for cornea transplants are in pain."

Surgeon availability is also a problem in some parts of the country. For example, there are only three corneal surgeons for all four Atlantic provinces and two ophthalmologists in western Newfoundland who perform corneal transplants, which definitely affects wait times, says Mary Gatien, president of the Canadian Association of Eye and Tissue Banks in Saint John, New Brunswick. "Sometimes you can have corneal tissue but not have a surgeon available to operate."

Vision loss is devastating, and the consequences can be dire. A 2008 report by the Canadian National Institute for the Blind noted that those with vision loss are three times more likely to experience clinical depression, at double the risk of falls and premature death and four times more at risk for serious hip fractures and earlier admissions to nursing homes. 
Ironically, last year, an excess of donations to Héma-Quebec meant supply outstripped demand in the province. Some 70 corneal tissues were offered to other eye banks across the country, but despite lengthy wait times because of insufficient tissues in other jurisdictions, there were no takers. The tissues were destroyed.

Germain suspects this happened because his organization does not have accreditation with the Eye Bank Association of America (EBAA), while eye banks in New Brunswick, Ontario, Saskatchewan, Alberta, Manitoba and $\mathrm{BC}$ do.

Héma-Québec complies with Health Canada's regulations and is accredited with the American Association of Tissue Banks. "We didn't see the need to add EBAA accreditation, which costs money and takes time, preparing for audits," Germain says. "Before Health Canada's regulations came into being in 2007, eye banks outside the US sought EBAA accreditation as a demonstration they knew what they were doing. But it's a voluntary accreditation, and it's not required to provide tissues in Canada." - Lauren Kramer, Vancouver, BC

CMAJ 2013. DOI:10.1503/cmaj.109-4517 